\title{
Servant Leadership as a Driver of Employee Service Performance: Test of a Trickle-Down Model and Its Boundary Conditions
}

\author{
Zhen Wang \\ Department of Organization and Human Resources Management \\ Business School, Central University of Finance and Economics
}

\author{
Haoying Xu \\ Department of Managerial Studies \\ University of Illinois at Chicago, USA
}

Yukun Liu*

Department of Management and Organization

University of Western Australia, Australia

\begin{abstract}
* Correspondence concerning this article should be addressed to Yukun Liu, Centre for Transformative Work Design, University of Western Australia, M261, 35, Stirling Highway, Crawley, WA 6009, Australia. Email: yukun.liu@uwa.edu.au.
\end{abstract}

Acknowledgements: All authors contributed equally to the development of this research. The authors would like to thank the Associate Editor Samuel Aryee and the three anonymous reviewers for their valuable comments on this article. This research was supported by funding from Beijing Social Science Fund (grant number: 16GLB035) and National Natural Science Foundation of China (grant numbers: 71302129 and 71772193). 
Servant Leadership as a Driver of Employee Service Performance: Test of a Trickle-Down Model and Its Boundary Conditions

\begin{abstract}
Previous research has demonstrated the role of servant leadership, a leadership style emphasizing serving others, in promoting frontline employees' service performance. It is unclear, however, how servant leadership by leaders at different organizational levels would exert such an influence. Integrating insights from both social learning theory and the trickle-down paradigm of leadership, we develop a cross-level model in which we argue that servant leadership by highlevel managers could cascade downward through the organizational hierarchy to influence frontline employees' service performance and that this trickle-down effect is contingent on the extent to which subordinates identify their leaders as embodying the organization. Using a matched sample of 92 supervisors and 568 frontline employees across 92 sub-branches of a large banking company, we found that servant leadership by high-level managers could indeed promote employees' in-role and extra-role service performance through its effect on low-level supervisors' servant leadership. We also found that this trickle-down effect was stronger when high-level managers and low-level supervisors were perceived by their subordinates as more fully embodying the organization. Implications, limitations, and future directions are discussed.
\end{abstract}

\title{
Keywords:
}

servant leadership, service performance, organizational embodiment, social learning theory, trickle-down effect 


\section{Introduction}

The service industry is playing an increasingly pivotal role in the global economy.

According to statistics from the World Bank, as of 2015, the value added created by the service sector has accounted for $68 \%$ of GDP across nations on average, and this percentage is still rising at a steady rate (World Bank, 2017). Against this background, a burgeoning body of research has been conducted to investigate what could contribute to frontline employees' service performance (e.g., Aryee et al., 2012; Liao and Chuang, 2004), as this performance has been regarded as one of the most crucial factors influencing a service organization's desirable customer outcomes and its long-term profitability (Hong et al., 2013; Subramony and Pugh, 2015).

Among the existing research on this topic, one emerging stream has focused on the role of servant leadership in eliciting excellent service performance, as it has been believed that the serving characteristics of this leadership style coincide perfectly with the service-oriented nature of service organizations (Liden et al., 2014). Unlike other leaders (e.g., transformational leaders), servant leaders lead by serving others (Graham, 1991; van Dierendonck et al., 2014): they not only serve followers by putting their interests and needs first but also extend beyond the organization to serve multiple stakeholders, including customers, communities, and even society as a whole (Liden et al., 2008; van Dierondonck, 2011). Extant research has found that servant leadership can positively influence service performance by cultivating the unit's serving culture and service climate (Hunter et al., 2013; Liden et al., 2014) or enhancing employees' self- 
efficacy, job satisfaction, and group identification (Chen et al., 2015; Neubert et al., 2016). Although these studies have provided valuable insights, more research is needed to further investigate how and when servant leadership influences employees' service toward customers.

The first notable issue is that prior research has primarily focused on the role of immediate supervisors' servant leadership in influencing service performance. However, that research has neglected the role of high-level managers' servant leadership, thereby failing to fully answer the question regarding how servant leadership at different hierarchical levels would influence frontline employees' service performance. Addressing this gap is theoretically important because doing so can extend the current knowledge about the role of servant leadership in service organizations of multiple hierarchies. As high-level managers usually set the "tone at the top" (Barney et al., 2005; Ruiz et al., 2011), servant leadership by high-level managers might foster frontline employees' service performance through a direct effect (i.e., the bypass effect). Additionally, because high-level managers are normally regarded as role models for subordinates, we propose that high-level managers' servant leadership may also elicit frontline employees' service performance through an indirect mechanism (i.e., trickle-down effect). Specifically, as one of the central tenets of servant leadership theory is the cultivation of servant leadership among followers through the role modeling process (Greenleaf, 1970; Graham, 1991), we propose a trickle-down model wherein high-level servant managers influence frontline employees' service performance through a role modeling process in which high-level servant managers cultivate immediate supervisors' servant leadership. Our rationale is based on social 
learning theory (SLT, Bandura, 1977) because the theory's notion of the role modeling process plays a central role in explaining the cultivation of servant leadership and the translation of servant leadership into employees' service performance (Liden et al., 2014).

The other important yet unanswered issue concerns the conditions under which servant leadership at different levels affects employees' service performance. Despite the accumulated knowledge regarding the mediating mechanisms linking servant leadership and service performance, the existing literature has not yet provided much insight about the potential boundary conditions of these effects (Chen et al., 2015; Neubert et al., 2016). According to SLT, the extent to which followers view leaders as role models and emulate their values, attitudes and behaviors is dependent on leaders' power, status and competence and on the legitimacy and acceptance of such values, attitudes and behaviors in the organization (Bandura, 1977; Manz and Sims, 1981). Building upon and extending this reasoning, we propose that supervisors' and employees' perceptions of the organizational embodiment of their leaders (i.e., high-level managers and immediate supervisors), which refers to the extent to which subordinates identify their leaders as embodying the organization (Eisenberger et al., 2010), would moderate the trickle-down effect of servant leadership on frontline employees' service performance. We make this prediction for two reasons: First, followers' perceived organizational embodiment of their leaders could serve as an important cue of leaders' power, status and competence, thus making leaders more likely to be viewed as role models; and second, followers' perceived organizational embodiment of their leaders could convey a message that their leaders' behaviors are congruent 
and consistent with the organization's rules and norms, thus making followers' imitation of their leaders' behaviors more appropriate, more acceptable, and more likely to occur (Mayer et al. 2009).

Taken together, as depicted in Figure 1, the current study aims to investigate the trickledown effect of servant leadership on frontline employees' service performance and attempts to address two important yet understudied research questions: (a) How does servant leadership at different organizational levels cascade downward to influence employees' service performance? (b) When is this trickle-down effect more likely to occur in the workplace? By doing so, we contribute to the literature in two significant ways. First, by demonstrating that servant leadership by high-level managers could trickle down to influence frontline employees' service performance through its effect on low-level supervisors' servant leadership, the current study extends prior research that has examined the relationship between servant leadership and service performance only at the dyadic level (e.g., Chen et al., 2015; Liden et al., 2014). To be specific, we provide a coherent system of social influence regarding service across three levels of an organization, which will help scholars form a more holistic understanding of the relationship between servant leadership and employees' service excellence. Second, by incorporating a recently emerged construct (i.e., organizational embodiment) into the trickle-down process by which servant leadership affects employees' service performance, and by examining organizational embodiment as a social learning-related moderator influencing the role modeling process of servant leadership, this research contributes to two bodies of literature: the servant 
leadership literature, by identifying a novel boundary condition for its effect on service performance and its trickle-down effect in the workplace, and the nascent organizational embodiment literature, by extending it to the social learning context that prior research has rarely focused only (Eisenberger et al., 2010; Shoss et al., 2013).

Insert Figure 1 about here

\section{Theory and Hypotheses}

\section{The Direct Effect of Servant Leadership on Employee Service Performance}

Servant leadership is a form of leadership that emphasizes serving others, such as employees (Greenleaf, 1977). For this reason, previous research has theorized that servant leadership can help shape employees' service-oriented values and behaviors, citing the tendency of followers to emulate their leaders as an explanatory mechanism (Graham, 1991). Based on this reasoning, we argue that servant leadership both at the supervisory level and at higher levels can influence frontline employees' service performance through a role modeling process.

SLT holds that individuals learn by witnessing and replicating the values and behaviors of role models and that "those who have high status, competence, and power are more effective in promoting others to behave similarity than are models of low standing" (Bandura, 1977: 88). As servant leaders occupy formal managerial positions, have particular competence (e.g., conceptual skills), and possess certain desirable characteristics that have garnered them a high status in the eyes of followers (e.g., behaving ethically, and prioritizing others' interests) (Liden et al., 2008; van Dierendonck, 2011), they would be viewed as role models and thus imitated by frontline 
employees. In addition, servant leadership has unique characteristics that make it closely linked to role modeling processes in organizations. For instance, as the ultimate goal of servant leadership is to cultivate followers to become servant leaders as well, servant leaders would naturally lead through role modeling and provide followers with opportunities to observe and imitate their values, attitudes and behaviors (Greenleaf, 1970; Liden et al., 2014).

Because they are viewed as role models, servant leaders can influence employees' service performance through a role modeling process. First, servant leaders demonstrate their servingoriented values, attitudes and behaviors to employees by satisfying followers' needs and interests (Neubert et al., 2016). Being served well by servant leaders, employees will be instilled with a strong desire and motivation to imitate such values, attitudes and behaviors and serve others (Liden et al., 2014). Although servant leadership behaviors are not the same as the behaviors of serving customers, both behaviors inherently involve the same component: the serving orientation. Thus, the serving-oriented values, attitudes and behaviors of servant leadership, to some extent, can be imitated by their followers to satisfy the needs and interests of the customers and to achieve superior service performance during the process of serving customers (Hunter et al., 2013). Second, in addition to caring about their followers, servant leaders care about the needs and interests of other stakeholders both inside and outside the organization (Liden et al., 2008; Neubert et al., 2016). These stakeholders certainly include customers, particularly in the service industry (Chen et al., 2015; Liden et al., 2014). Therefore, we conjecture that during their interaction with followers, servant leaders might emphasize the importance of prioritizing and 
satisfying customers' needs and encourage employees to model their serving-oriented attitudes and behaviors during the process of serving customers.

In the current study, we simultaneously consider the servant leadership of both immediate supervisors and high-level managers. Previous research has provided support for the role of supervisory servant leadership (e.g., Chen et al., 2015; Hunter et al., 2013; Liden et al., 2014; Neubert et al., 2016). Regarding high-level managers, because they are often perceived as more powerful and competent and higher in status (Ruiz et al., 2011), and they usually set the "tone at the top" (Barney et al., 2005) to shape the service climate within the organization (Huang et al., 2016; Peterson et al., 2012), their servant leadership should also exert a positive effect on frontline employees' service performance.

To present a more holistic picture of this effect, we specifically examine servant leadership's influence on both the in-role and extra-role service performance of employees. Inrole service performance refers to an employee's serving and helping customers as specified in their job description, whereas extra-role service performance refers to an employee's discretionary behaviors in serving customers that extend beyond the formal job requirements (Bettencourt and Brown, 1997). These two forms of service performance are distinguishable and should be considered separately as they capture different components of job performance in the customer-service context (Motowidlo and Van Scotter, 1994). Despite this distinction, it is surprising that prior research has focused primarily on in-role service performance (cf. Chen et al., 2015). As both in-role and extra-role service performance relate to external aspects of service 
effectiveness, such as customer satisfaction and financial performance (Hong et al., 2013;

Netemeyer et al., 2005), it is essential and useful to examine whether both could be promoted through internal factors that emphasize service as well, such as servant leadership.

H1: Supervisors' servant leadership is positively related to frontline employees' service performance.

H2: Managers' servant leadership is positively related to frontline employees' service performance.

\section{The Trickle-Down Effect of Servant Leadership on Employee Service Performance}

As Greenleaf (1970) suggested, servant leaders serve followers by cultivating servant leaders among their followers, which implies a trickle-down effect of servant leadership along the organizational hierarchy (Aryee et al., 2007). According to SLT, as supervisors occupy lower-level positions in a hierarchical organization, they may view their immediate superiors as role models and observe them to learn values, norms, and behaviors that are appropriate or acceptable in the organization (Bandura, 1977). In the current study, we posit that supervisors would view their immediate superiors (i.e., high-level servant managers) as role models and emulate their servant leadership behaviors, thus becoming servant leaders as well. In addition, given that cultivating servant leaders among followers is one of the major goals of servant managers (Greenleaf, 1970), a servant manager might inform his or her followers that he or she expects them to become servant leaders and, accordingly, provide professional and personal 
guidance to followers (i.e., immediate supervisors) to encourage them to adopt servant leadership (Liden et al., 2014).

Relying on SLT, we further posit that the trickle-down effect of servant leadership would ultimately carry over to influence frontline employees' service performance. In other words, managers' servant leadership may exert a cross-level influence on frontline employees' service performance via the mediating role of similar leadership behaviors by immediate supervisors. Although individuals tend to emulate models who have status, competence and power, their perceived similarity to the models is a critical factor that could affect the actual modeling process (Bandura, 1977; Goldstein and Sorcher, 1974). As stated in SLT, individuals tend to select a proximal rather than a socially and psychologically distant other as a model for learning and emulating behaviors. In the organizational context, compared with distal high-level managers, immediate supervisors' leadership is more proximal to frontline employees and thus could have stronger effects on employees' attitudes and behaviors (Cole et al., 2009). Such effects may arise because immediate supervisors have closer and more frequent communications with employees and can better interpret policies or directly administer rewards or punishment (Liu et al., 2012; Mayer et al., 2009). As such, we argue that by influencing employees' immediate supervisors to become servant leaders, high-level managers are able to instill their service-oriented values and behaviors in frontline employees. Hence, we expect a trickle-down effect wherein the servant leadership of high-level managers would first cascade to immediate supervisors and then affect frontline employees' service performance. 
H3: Managers' servant leadership positively affects frontline employees' service performance via supervisors' servant leadership.

\section{The Moderating Effects of Organizational Embodiment}

A leader's organizational embodiment represents an individual's belief concerning the shared identity between the leader and the organization (Eisenberger et al., 2010; Shoss et al., 2013). According to Eisenberger and colleagues $(2010,2014)$, the higher a leader's embodiment is, the more a follower views a leader as representing the organization and the more power and influence this leader has in the eyes of followers. SLT suggests that individuals learn from role models by witnessing and replicating their values and behaviors. The theory also suggests that those who have high status, competence, and power are more effective in promoting others to observe and emulate (Bandura, 1977), and those behaviors that are legitimate and acceptable are more likely to be observed and imitated (Manz and Sims, 1981). Based on these arguments, as well as the conceptual meaning of leader's organizational embodiment, we consider organizational embodiment a boundary condition for the relationships we previously proposed.

We posit that high-level managers' organizational embodiment (MOE), as perceived by supervisors, facilitates the trickle-down effect of servant leadership. First, MOE serves as an important cue of managers' power, status, and competence, particularly in the eyes of their followers (i.e., supervisors) - making them more likely to be viewed as role models. In the organizational context, because managers act as major representatives of their organizations, managers' formal status and a substantial part of their power come from the powerful and 
resource-abundant organization. However, the extent to which supervisors identify their managers as representatives of the organization differs among individuals; hence, manager' status and power in the eyes of different supervisors may also vary (Eisenberger et al., 2010). Specifically, the more managers are viewed as embodying an organization, the more likely they are to be perceived as supported by the authority of the organization and thus would have more power and higher status_-making them more likely to be viewed as role models. Second, MOE conveys a message that managers' behaviors are congruent or consistent with the organization's rules and norms, therefore making supervisors' imitation of managers' behaviors appropriate and acceptable in the organization — encouraging them to learn more from the servant managers (Mayer et al., 2009). In the highly institutional context in particular (e.g., the banking industry), where rules and norms are of great importance, supervisor would be more likely to comply with and learn from managers who have much in common with the organization, as the values and behaviors of these leaders would be viewed as the defining values and characteristics of the organization. Hence, we postulate that MOE could amplify servant managers' status and power as perceived by supervisors and thus facilitate supervisors' emulation of their immediate managers' servant leadership behaviors. Combining this argument with the trickle-down effect previously suggested, we propose a first-stage moderated mediation model in which MOE strengthens the trickle-down effect of high-level managers' servant leadership on frontline employees' service performance. 
H4a: Managers' organizational embodiment strengthens the positive indirect effect of managers' servant leadership on frontline employees' service performance via supervisors' servant leadership.

Based on the same reasoning, we further suggest that supervisors' organizational embodiment (SOE), as perceived by frontline employees, could also reinforce the positive link between supervisors' servant leadership and frontline employees' service performance. Drawing upon SLT (Bandura, 1977), we suggest that SOE could strengthen frontline employees' willingness to view supervisors as role models because those who rate SOE more highly may be more likely to perceive their supervisors as having more power and higher status and thus would regard the emulation of servant supervisors as more acceptable and more appropriate in the organization. This perception would further facilitate frontline employees' emulation of supervisors' service-oriented attitudes, values and behaviors, which would lead to better service performance. Thus, we propose a second-stage moderated mediation model in which SOE strengthens the trickle-down effect of high-level managers' servant leadership on frontline employees' service performance.

H4b: Supervisors' organizational embodiment strengthens the positive indirect effect of managers' servant leadership on frontline employees' performance via supervisors' servant leadership.

Integrating $\mathrm{H} 4 \mathrm{a}$ and $\mathrm{H} 4 \mathrm{~b}$, we take a further step by simultaneously examining the moderating effects of both supervisors' and employees' perceptions of the organizational 
embodiment of their superiors (i.e., high-level managers and immediate supervisors, respectively). As such, we propose a dual-stage moderated mediation model wherein the indirect effects of high-level managers' servant leadership on frontline employees' service performance are conditional on the combination of both MOE and SOE.

H5: The positive indirect effects of managers' servant leadership on frontline employees' service performance via supervisors' servant leadership are conditional on the combination of managers' and supervisors' organizational embodiment, such that the indirect effect would be the strongest when both MOE and SOE are perceived to be higher.

\section{Method}

\section{Sample and Procedure}

We collected data from a large banking company in China to investigate the proposed research questions. Specifically, we collected multilevel and multisource data from 92 subbranches, which are nested within 19 higher-level branches of the bank. At the most basic level in the organizational hierarchy of the banking company, a sub-branch operates as a team consisting of a supervisor and a group of frontline employees who have direct contact with customers. Every sub-branch is under the control of a high-level manager from the corresponding regional branch of the company; thus, a sub-branch encompasses three management levels: the high-level manager, the low-level sub-branch supervisor, and frontline employees. 
Using our alumni contacts and personal social network, we approached one hundred out of all 120 sub-branches of the bank. To reduce common method bias, we distributed two different sets of questionnaires to supervisors and frontline employees separately. Included within each questionnaire was a cover letter that explained the purpose of the research and assured that individual responses would remain confidential and that participants could withdraw from the research at any time. To ensure the effectiveness of the survey, we collected data on site during participants' working hours. Frontline employees were asked to rate their supervisors' servant leadership, SOE, and the perception of the work unit's service climate (control variable). Meanwhile, supervisors were asked to rate their direct managers' servant leadership, MOE, and their subordinates' service performance.

Ultimately, we collected data from 568 frontline employees and 92 supervisors. The employee-to-supervisor ratio ranged from 4 to 10, with an average of 6.17. Among supervisors, $52 \%$ were female, the average age was 40.09 years old $(S D=5.90)$, and the average tenure in the supervisor position was 2.64 years $(S D=1.19)$; the majority $(87 \%)$ had a four-year college degree or above. Among frontline employees, 39\% were female, $84.5 \%$ had a bachelor's degree or above, the average age was 31.95 years old $(S D=6.65)$, and the average of years working with current supervisors was 2.37 years $(S D=1.13)$.

\section{Measures}

All measures were rated by the respondents on a 5-point Likert scale. The anchors for each measure ranged from strongly disagree (1) to strongly agree (5). 
Manager and supervisor servant leadership. We measured servant leadership with Liden and colleagues' (2015) 7-item scale. A sample item is "My leader puts my best interests ahead of his/her own." Specifically, manager servant leadership was rated by supervisors, while supervisor servant leadership was rated by frontline employees. Cronbach's alphas were .92 for supervisor servant leadership and .85 for manager servant leadership. As both employees' and supervisors' ratings were nested within a higher-level group, we aggregated employees' and supervisors' responses to the sub-branch level and the branch level, respectively. To verify the appropriateness of our aggregating decision, we calculated the within-group agreement $\left(r_{\mathrm{wg}}\right)$ and two intra-class correlations: ICC(1) and ICC(2). For supervisor servant leadership, the mean $r_{\mathrm{wg}}$ and median $r_{\mathrm{wg}}$ of the 92 sub-branches were .92 and .94 , respectively, surpassing the recommended cutoff value of .70 (LeBreton and Senter, 2008). The ICC(1) and ICC(2) values were .58 and .89 , and results also showed that servant leadership varied significantly across subbranches $(F=9.43, p<.01)$. All these coefficients provided support for the aggregation of supervisors' servant leadership (LeBreton and Senter, 2008). Cronbach's alpha for the scale after aggregation was .96. However, although the mean $r_{\mathrm{wg}}$ and median $r_{\mathrm{wg}}$ of the 19 branches were .83 and .85 , respectively, neither ICC(1) (.02) nor ICC(2) (.10) could justify the aggregation of supervisor-rated managers' servant leadership to the branch level (James, 1982; LeBreton and Senter, 2008). In addition, there were no substantial variations across high-level branches with respect to managers' servant leadership $(F=1.12, p=.36)$. Therefore, we used supervisors' perceived servant leadership of high-level managers in our hypotheses testing. 
Manager and supervisor organizational embodiment. We measured organizational embodiment with 9 items from the scale developed by Eisenberger and colleagues (2010). A sample item is "When my leader encourages me, I believe that the organization is encouraging me." Leaders' organizational embodiment was rated by their immediate followers. Cronbach's alphas for supervisor organizational embodiment and for manager organizational embodiment were both .96. For SOE, because the mean $r_{\mathrm{wg}}$ and median $r_{\mathrm{wg}}$ of the 92 sub-branches were .88 and .90 , respectively, the ICC(1) and ICC(2) values were .33 and .76 , respectively, and SOE varied significantly across sub-branches $(F=4.08, p<.01)$, we aggregated frontline employees' responses regarding their supervisor's organizational embodiment to the sub-branch level. Cronbach's alpha for the scale after aggregation was .97. For MOE, we followed Eldor and Harpaz's (2016) approach and used supervisors' perceptions of managers' organizational embodiment in our analyses, as neither ICC(1) (.11) nor ICC(2) (.36) nor the between-branch level variance $(F=1.57, p=.09)$ supported the aggregation of supervisors' ratings of MOE to the branch level (the mean $r_{\mathrm{wg}}$ and median $r_{\mathrm{wg}}$ of the 19 branches were .78 and .81 , respectively).

Employee in-role and extra-role service performance. In-role service performance was assessed with 5 items from Liao and Chuang's (2004) measure $(\alpha=.92)$. A sample item is "This employee asks good questions and listens attentively to find out what a customer wants." Extrarole service performance was measured with Dimitriades's (2007) 7-item scale $(\alpha=.93)$. A sample item is "To serve the customers, this employee volunteers for things that are not required." The results of CFA revealed that the theorized two-factor model provided a good 
model fit $\left(\chi^{2}=443.75, d f=53, \mathrm{SRMR}=.05, \mathrm{CFI}=.97, \mathrm{TLI}=.97\right)$ and fit the data better than the single-factor model did $\left(\Delta \chi^{2}{ }_{(1)}=1683.99, p<.01 ; \mathrm{SRMR}=.09, \mathrm{CFI}=.90, \mathrm{TLI}=.88\right)$, suggesting that in-role and extra-role service performance were distinguishable.

Control variables. We controlled for supervisors' age, gender, education, and position tenure at level 2. At level 1, in addition to employees' age, gender, education and dyadic tenure with the current supervisor, we controlled for their perception of the work unit's service climate, as this climate has been argued to be an important antecedent of employees' service performance (Hong et al., 2013). We measured this variable using Schneider et al.'s (1998) 7-item scale ( $\alpha$ $=.94$ ). One sample item was "The overall quality of service provided by our team is excellent." We conducted CFA to examine the distinctiveness of the five variables measured at level 1 (i.e., supervisors' servant leadership, SOE, service climate perception, in-role, and extra-role service performance). The hypothesized 5-factor model shows a satisfactory fit $\left(\chi^{2}(550)=\right.$ $3936.66, \mathrm{SRMR}=.06, \mathrm{CFI}=.97, \mathrm{TLI}=.97)$, thus supporting the discriminant validity of the research variables. We also compared the hypothesized model with several alternative models and found that the hypothesized model fit the data better than models constraining in-role and extra-role service performance to be part of the same factor $\left(\Delta \chi^{2}(4)=1749.43, p<.01\right)$, combining supervisor servant leadership and organizational embodiment $\left(\Delta \chi^{2}{ }_{(4)}=3230.76, p\right.$ $<.01)$, constraining variables reported by the same sources $\left(\Delta \chi^{2}(9)=7674.62, p<.01\right)$ and collapsing all variables into one factor $\left(\Delta \chi^{2}{ }_{(10)}=10304.60, p<.01\right)$. We also performed CFA to examine the distinctiveness of the two variables measured at level 2 (i.e., managers' servant 
leadership, and managers' organizational embodiment). The results also suggested that the hypothesized two-factor model fit the data well $\left(\chi^{2}(103)=316.41, \mathrm{SRMR}=.08, \mathrm{CFI}=.93\right.$, TLI $=.92)$ and better than the one-factor model did $\left(\Delta \chi^{2}{ }_{(1)}=203.52, p<.01\right)$. These results in general suggest that the variables in the current study had decent discriminant validity.

\section{Analytical Strategy}

Given the nested nature of the data, we conducted multilevel modeling to test the hypotheses. Specifically, we tested $\mathrm{H} 1$ and $\mathrm{H} 2$ with an intercepts-as-outcomes model using HLM 6.08 , in which we used supervisors' and managers' servant leadership (level-2 predictor) to predict the intercepts of employees' in-role and extra-role service performance (level-1 outcomes). We centered the predictors according to their grand mean in performing these analyses to control for multicollinearity. To test multilevel mediations and moderated mediations, we conducted multilevel path analyses using Mplus 7.0. Specifically, in testing the cross-level mediation effects (H3), we relied on Bauer et al.'s (2006) work on multilevel mediation and estimated the indirect effects based on a 2-2-1 path-analytical model. In testing the moderated mediation effects ( $\mathrm{H} 4 \mathrm{a}, \mathrm{H} 4 \mathrm{~b}$, and $\mathrm{H} 5)$, we used the formulas reported by Preacher et al. (2007) and estimated the conditional indirect effects (i.e., the indirect effects at one $S D$ above or below the mean of the moderator) in three separate path-analytical models. To examine the significance of each indirect effect we estimated, we conducted a Monte Carlo simulation with 20,000 replications, which provided an estimate of the confidence interval for each indirect effect. 


\section{Results}

\section{Descriptive Statistics}

The means, standard deviations and correlations among the variables are presented in Table 1 (for level-1 variables) and Table 2 (for level-2 variables). As shown in Table 1, supervisors' servant leadership was positively correlated with both the in-role $(r=.43, p<.01)$ and extra-role $(r=.50, p<.01)$ service performance of employees. At level 2 , supervisors' servant leadership (aggregated) was positively correlated with the aggregated in-role service performance ( $r=.29$, $p<.01)$ and extra-role service performance $(r=.31, p<.01)$ of employees. Managers' servant leadership was positively related to the aggregated in-role $(r=.40, p<.01)$ and extra-role service performance $(r=.40, p<.01)$ as well.

Insert Table 1 and Table 2 about here

\section{Tests of Hypotheses}

H1 and $\mathrm{H} 2$ predicted that supervisors' and managers' servant leadership would be positively related to frontline employees' in-role and extra-role service performance. Before testing this hypothesis, we examined whether there was significant between-group variance in employees' service performance. The results of two separate null HLM models revealed significant betweengroup variance in both employees' in-role service performance $\left(\sigma^{2}=.20, \tau^{00}=.13, \chi^{2}=431.24, p\right.$ $<.01 ; \operatorname{ICC}(1)=.39$, indicating that $39 \%$ of the variance can be attributed to the group level) and extra-role service performance $\left(\sigma^{2}=.29, \tau^{00}=.16, \chi^{2}=422.94, p<.01 ; \operatorname{ICC}(1)=.36\right.$, indicating 
that $36 \%$ of the variance can be attributed to the group level). Thus, the results justified the appropriateness of using HLM to test the hypotheses.

To test H1 and H2, we ran a regression model in which the effects of supervisors' and managers' servant leadership were examined simultaneously. As shown in Table 3, after we controlled for the variables at both the individual level and the group level, supervisors' servant leadership significantly predicted frontline employees' in-role $(B=.15, p<.01)$ and extra-role $(B$ $=.13, p<.05)$ service performance. Thus, $\mathrm{H} 1$ was supported. Furthermore, the results revealed that managers' servant leadership significantly predicted frontline employees' in-role service performance $(B=.11, p<.05)$ but did not predict extra-role service performance $(B=-.01, n s)$. $\mathrm{H} 2$ received partial support.

Insert Table 3 about here

H3 proposed that supervisor servant leadership would mediate the relationship between manager servant leadership and employee service performance. Multilevel path analyses revealed that the indirect effect of manager servant leadership on employees' in-role service performance was .05 ; the $95 \%$ confidence interval was $[.01, .09]$, which did not contain zero, suggesting that the indirect effect is significant ${ }^{1}$. The indirect effect on employees' extra-role

\footnotetext{
1 As service climate, aggregated from frontline employees' ratings of service climate perceptions, might be an alternative account for the indirect effect of high-level managers' servant leadership on employees' service performance, we conducted a number of additional analyses using the aggregated service climate variable (both $R \mathrm{wg}(.88)$ and $\operatorname{ICC}(1)(.46)$ justified the aggregation of individual-level ratings). The results revealed that service climate could indeed mediate the effect of high-level managers' servant leadership on employees' service performance (estimate $=.19, p<.01$, for in-role performance; estimate $=.23, p<.01$, for extra-role performance), and the indirect effects through service climate were stronger than the indirect effects through supervisors' servant leadership (estimate $=.14, p<.01$, for in-role performance; estimate $=.18, p<.01$, for extra-role performance; note that the results were obtained from a model without controlling for service climate to make the abovementioned comparisons comparable). When incorporating both mediators into the same model (dual-path mediation model), however, none of the mediation effects could still hold, largely because of the high correlation $(r=.79)$ between supervisors' servant leadership and service climate (as both were aggregated from individual-level ratings). As the trickle-down
} 
service performance was also significant at .05 , with the $95 \%$ confidence interval being $[.01, .11]$. Thus, H3 was supported.

$\mathrm{H} 4 \mathrm{a}$ suggested that MOE would serve as a first-stage moderator and moderate the mediation effect as proposed in $\mathrm{H} 3$. Before testing the moderated mediation, we conducted a simple moderation analysis to determine whether MOE functioned as a moderator between manager servant leadership and supervisor servant leadership. The results revealed that the interactive terms (i.e., manager servant leadership $\times \mathrm{MOE})$ had a positive effect $(B=.29, p<.05)$ on supervisor servant leadership after controlling for the independent effects of manager servant leadership and MOE. Specifically, the effect of manager servant leadership on supervisor servant leadership was stronger $(B=.52, p<.01)$ when MOE was higher and weaker $(B=.14, n s)$ when MOE was lower (Figure 2a). Furthermore, we built upon the model used in testing H3 and added MOE as a first-stage moderator to test the moderated mediation. We computed the indirect effects at both higher $(+1 S D)$ and lower $(-1 S D)$ levels of MOE and compared the conditional indirect effects. The results showed that the indirect effect of manager servant leadership on employees' in-role service performance was significant when MOE was higher (estimate $=.08$, $95 \% \mathrm{CI}=[.01, .14])$ and insignificant when MOE was lower $($ estimate $=.02,95 \% \mathrm{CI}=$ $[-.03, .07])$. Similarly, the indirect effect on employees' extra-role service performance was also

mechanism studied in the current research is not the only mechanism linking high-level managers' servant leadership with employees' service performance, and what actually motivated us to conduct this research were our interest in and curiosity about the trickle-down phenomenon in the servant leadership context, which naturally had been proposed as the central mechanism that we intended to investigate, we used supervisory servant leadership as the mediator in the current study. We thank an anonymous reviewer for encouraging us to consider this possibility. 
significant when MOE was higher (estimate $=.08,95 \% \mathrm{CI}=[.02, .13])$ and insignificant when MOE was lower $($ estimate $=.02,95 \% \mathrm{CI}=[-.03, .07])$. Given these results, H4a was supported.

Insert Figure $2 \mathrm{a}$ about here

We used the same method to test H4b. In this case, SOE was added as a second-stage moderator of the mediation model. Prior to testing the proposed model, we tested two simple moderation effects models in which SOE strengthened the relationship between supervisor servant leadership and service performance. The results indicated that the interactive terms (supervisor servant leadership $\times \mathrm{SOE})$ were positively related to both in-role $(B=.26, p<.01)$ and extra-role service performance $(B=.20, p<.05)$. Figure $2 \mathrm{~b}$ and Figure $2 \mathrm{c}$ depict the interactive effects of supervisors' servant leadership and SOE on frontline employees' in-role and extra-role service performance, respectively. Based on these results, we conducted an analysis to test the moderated mediation effects. Estimation of the conditional indirect effects revealed that the indirect effect of manager servant leadership on employees' in-role service performance was significant when SOE was higher (estimate $=.07,95 \% \mathrm{CI}=[.02, .12])$ and insignificant when SOE was lower (estimate $=-.00,95 \% \mathrm{CI}=[-.06, .06])$. Similarly, the indirect effect on employees' extra-role performance was marginally significant when SOE was higher (estimate $=.05,90 \% \mathrm{CI}=[.004, .09], 95 \% \mathrm{CI}=[-.004, .10])$ and insignificant when SOE was lower (estimate $=-.02,95 \% \mathrm{CI}=[-.08, .05])$. Thus, H4b was supported.

Insert Figure $2 \mathrm{~b}$ and $2 \mathrm{c}$ about here 
Finally, H5 suggested a dual-stage moderated mediation model wherein the indirect effect of high-level managers' servant leadership on frontline employees' service performance is conditional on the combination of MOE and SOE. Estimation of the conditional indirect effects (with 4 combinations of MOE and SOE: high-high, high-low, low-high, and low-low) revealed that the indirect effect of manager servant leadership on employees' in-role service performance was significant only when both MOE and SOE were higher (estimate $=.10,95 \% \mathrm{CI}=[.02, .19])$. Similarly, the indirect effect on employees' extra-role service performance was marginally significant only when both MOE and SOE were higher (estimate $=.07,90 \% \mathrm{CI}=[.01, .12], 95 \%$ $\mathrm{CI}=[-.001, .13])$. Thus, $\mathrm{H} 5$ was also supported (though the effect is relatively weaker). The conditional indirect effects for $\mathrm{H} 4 \mathrm{a}, \mathrm{H} 4 \mathrm{~b}$ and $\mathrm{H} 5$ are summarized in Table 4.

Insert Table 4 about here

\section{Discussion}

Understanding leadership styles relevant to cultivating excellent service has become an important research question for both management and service researchers. One stream of research responding to this question has investigated the role of servant leadership in eliciting followers' service performance within the supervisor-follower dyadic context (e.g., Chen et al., 2015; Liden et al., 2014). The purpose of this study was to extend beyond this existing research stream by also taking high-level managers' servant leadership into consideration and by simultaneously investigating how and when servant leadership at different hierarchical levels influence frontline employees' service performance. We tested research questions using a sample 
from a large banking firm. The results generally supported our hypotheses. The findings offer several implications for theory and practice.

\section{Theoretical Implications}

First, this research deepens understanding of the servant leadership —employee service performance relationship by unraveling the roles of leadership at different hierarchical levels within an organization. Consistent with prior research, our results reveal that supervisory servant leadership has a positive effect on frontline employees' in-role and extra-role service performance. By moving beyond the supervisor-employee dyadic context on which most research has focused (e.g., Chen et al., 2015; Hunter et al., 2013; Liden et al., 2014), we investigate the role of high-level managers' servant leadership in eliciting employees' service performance. The results in general demonstrate that high-level managers' servant leadership has both a direct bypass effect and an indirect cascading effect on employees' service performance. The direct effect suggests that servant leadership can bypass hierarchical links and affect lower organizational levels (van Dierendonck, 2011).

More importantly, our study reveals an indirect trickle-down effect in which servant leadership by high-level managers promotes employees' in-role and extra-role service

performance through its effect on low-level supervisors' servant leadership. This finding suggests that the influence of servant leadership on service performance could operate beyond the dyadic level. As illustrated, there is a cycle of service among high-level managers, low-level supervisors and frontline employees within an organization, and such a full-range system of 
social influences should be considered when disentangling the role of leadership in promoting employee service excellence (Subramony and Pugh, 2015). This finding extends the service profit chain theory (Heskett et al., 1997) by presenting a service chain embedded in multiple hierarches of organizations in which high-level managers' provision of internal service to lowlevel supervisors spills over to low-level supervisors' internal service to frontline employees, which in turn spills over to employees' external service to customers. By revealing this trickledown effect, the present study also extends our understanding about the underlying mechanism though which servant leadership affects the workplace. Although studies have revealed several mediators (e.g., self-efficacy, job satisfaction, service climate, and serving culture) between servant leadership and service performance (e.g., Chen et al., 2015; Hunter et al., 2013; Liden et al., 2014; Neubert et al., 2016), these insights are not sufficient to gain a full understanding of how servant leadership influences employees' service excellence, as researchers are still calling for further examination of other potential mediators, particularly those unique to servant leadership (Liden, Panaccio et al., 2014). The current study contributes to understanding of the intermediate mechanism by adding servant leadership itself as a new mediator. This approach is noteworthy because as the central tenet of servant leadership theory is that servant leaders groom followers to be servant leaders (Greenleaf 1970), servant leadership is theorized to act as a critical mediator that transmits the effect of high-level servant leadership. However, this result should be interpreted with caution because the mediating effect of supervisors' servant leadership between high-level managers' servant leadership and employees' service performance 
did not hold when service climate was considered as the other mediator, and in this case, service climate did not mediate the relationship either. We encourage future research to portion the mediating effects of these two mediators using a more vigorous method.

Second, this study advances our knowledge regarding the boundary conditions of the servant leadership—service performance relationship as well as the trickle-down effect of servant leadership. Although research has investigated the effect of servant leadership on service performance, with few exceptions (e.g., Chen et al., 2015; Neubert et al., 2016), limited efforts have been devoted to examining the boundary conditions for such an effect. By examining supervisors' perceived MOE and employees' perceived SOE as moderators, the current study indicates that when followers strongly identify their leaders with the organization, they are willing to view servant leaders as role models and imitate their service-oriented values, attitudes and behaviors, and thus engage in excellent service performance; otherwise, servant leadership has no effect on service performance. This result suggests that servant leadership is not always powerful in eliciting employees' service excellence. By identifying the moderating role of leaders' organizational embodiment in the trickle-down effect of servant leadership, our study also illustrates when servant leaders could nurture some of their followers to be servant leaders and thus enriches our knowledge of the central tenet of servant leadership theory (Greenleaf, 1970). Moreover, by employing SLT as the basis for incorporating organizational embodiment into the trickle-down process, this study also contributes to the nascent literature on this new construct. Prior literature primarily relied on social exchange theory (SET) and claimed that 
followers with stronger perceptions of organizational embodiment of their leaders are more likely to generalize their favorable/bad relationships with leaders to their relationship with the organization and, accordingly, are more likely to reciprocate/retaliate the organization (e.g., Eisenberger et al., 2014; Shoss et al., 2013). In the current study, we built upon and further extended the organizational embodiment perspective to the social learning context; thus, we have suggested new possibilities for better understanding the organizational embodiment phenomenon in the workplace.

Although the findings have provided general support for our prediction, there is an unexpected yet interesting finding that is worth further discussion. Specifically, the hypothesized direct effect of managers' servant leadership on employees' extra-role service performance was not observed $(B=-.01, n s)$ when the effect of supervisor's servant leadership $(B=.13, p<.01)$ was incorporated into the model. This finding suggests that supervisors' servant leadership is stronger than managers' servant leadership in predicting extra-role service performance. One possible reason for this observation is related to the distance issue in the social learning process. According to SLT, the social learning effect is affected by the proximity between individuals and role models (Bandura, 1977; Kalkstein et al. 2006). Extra-role service performance is a set of discretionary behaviors that are primarily driven by employees' internalized serving beliefs or prosocial values (Chan and Wan 2012), which are deep-level characteristics that are not easy to observe directly. To induce such beliefs or values among employees, servant leaders must establish an intimate interaction with them and provide them with opportunities to observe and 
emulate. Because supervisors work closely with employees, their serving beliefs or values embedded in servant leadership behavior are more likely to be learned by frontline employees and thus could be more likely to promote their extra-role service performance. In contrast, because high-level managers are physically and psychologically distal to frontline employees, their serving beliefs and values are less likely to be observed or perceived, thus making it difficult to directly promote frontline employees' extra-role service performance (Manz and Sims, 1981). In support of this argument, Yaffe and Kark (2011) found that leader distance was a baffle for followers' imitation of their leaders' extra-role citizenship behaviors. In general, this finding suggests that immediate supervisors should be more encouraged to demonstrate servant leadership behaviors to promote extra-role service performance among frontline employees.

\section{Practical Implications}

Our research findings have several practical implications, particularly for service organizations, among which providing high-quality service to customers has become a strategic opportunity to create financial values (Aryee et al., 2012). First, as our study clearly demonstrates the importance of promoting servant leadership in service organizations, service organizations are suggested to invest efforts in nurturing servant leadership. Specifically, organizations are encouraged to design and implement training programs to promote servant leadership throughout all leadership levels. In particular, organizations should incorporate servant leadership modules into high-level managers' training programs. We believe this approach could be an important initiative as not many organizations have paid sufficient 
attention to high-level managers' servant leadership. Second, our findings demonstrate that followers would be more likely to respond, in terms of their serving behavior, to servant leaders who are perceived as embodiments of the organization. This result suggests a need for organizations to promote leaders' organizational embodiment. The organization should take initiatives to help leaders identify strongly with the organization in practicing their leadership, as research has shown that leaders who identify more strongly with organizations are more likely to be viewed as the embodiment of organizations by their employees (Eisenberger et al., 2010). This higher level of embodiment could be achieved by creating a collective corporate vision, culture, and goal, providing opportunities for leaders and establishing affective connection between them and the organization. In addition, organizations should provide more opportunities for leaders to share their thoughts, attitudes, or feelings toward the organization with followers and for employees to better understand their leaders. Such opportunities could be provided by creating more interactive sessions connecting leaders and followers, encouraging them to not only talk about work but also share their views about the organization.

\section{Limitations and Future Directions}

Our research is not without limitations. First, although we theoretically delineated the causal relationships among variables, the cross-sectional nature of the data limited our ability to establish causal relations. Using a longitudinal design would be of great value in improving our understanding of the multilevel influence of leadership. The second limitation concerns the use of supervisors' ratings of service performance, instead of the use of more objective performance 
data from customers. Ideally, future research would validate our results with more objective indicators of service performance, such as the number of customer complaints or the length of customers' waiting time. Third, as previously mentioned, because there was no substantial variation across high-level branches with respect to supervisors' perceptions of their managers' servant leadership and organizational embodiment, we could not properly operationalize highlevel managers' servant leadership as a level-3 variable and conduct robust three-level modeling to analyze the proposed relations. Although many studies have employed our same approach (e.g., Liu et al., 2012), we believe that future research employing a pure three-level data structure (particularly with enough ratings for high-level variables) would provide a more robust test of the trickle-down effect of servant leadership proposed in this study.

Fourth, although we used SLT as an account to explain the effects of servant leadership, we did not explicitly measure any core variables of this theory (e.g., role model strength, service self-efficacy) to directly test such an account. In addition, as we observed in the supplementary analysis, the trickle-down mechanism is not the only mechanism linking high-level managers' servant leadership to employees' service performance. Other mechanisms, such as social exchange, social identity, and individualized motivation, might also (and perhaps better) explain such an effect. We encourage future research on these alternative underlying mechanisms (Chiniara and Bentein, 2016). Finally, although we identified leaders' organizational embodiment as a boundary condition for the relationship between manager- and supervisorservant leadership or for the relationship between supervisor servant leadership and employee 
service performance, we did not consider the moderating effect of frontline employees'

perceived organizational embodiment of those high-level managers on the relationship between high-level managers' servant leadership and employees' service performance. As one reviewer suggested, because high-level managers' servant leadership functions as a prominent driver for employee's service performance (as our H2 suggested), high-level managers' organizational embodiment in the eyes of those frontline employees might exert an even stronger moderating effect than supervisors' perceived organizational embodiment of high-level managers does.

\section{Conclusion}

In response to recent calls for leadership research at multiple levels, this study examined how servant leadership at different levels functions as a driver for frontline employee' service performance. Drawing on social learning theory and the trickle-down paradigm of leadership, we examined how and when servant leadership at supervisory and managerial levels promotes frontline employees' service performance. The findings reveal that (a) servant leadership by high-level managers could indeed promote employees' in-role and extra-role service performance through its effect on low-level supervisors' servant leadership; and (b) this trickledown effect was stronger when high-level managers and low-level supervisors were perceived by their subordinates as more fully embodying the organization. Our results suggest that the servant leadership behaviors of leaders, at either supervisory or higher managerial levels, should be promoted because the presence of such leadership behavior would induce high levels of service performance among frontline employees. Furthermore, our results suggest a need for 
organizations to promote leaders' organizational embodiment to enhance the effectiveness of servant leadership in cultivating the service excellence of frontline employees.

\section{References}

Aryee S, Walumbwa FO, Seidu EYM and Otaye LE (2012) Impact of high-performance work systems on individual- and branch level performance: Test of a multilevel model of intermediate linkages. Journal of Applied Psychology 97(2): 287-300.

Aryee S, Chen ZX, Sun L-Y and Debrah YA (2007) Antecedents and outcomes of abusive supervision: Test of a trickle-down model. Journal of Applied Psychology 92(1): 191-201.

Bandura A (1977) Social Learning Theory. Englewood Cliffss, NJ: Prentice-Hall.

Barney JB (2005) Should strategic management research engage public policy debates? Academy of Management Journal 48(6): 945-948.

Bauer DJ, Preacher KJ and Gil KM (2006) Conceptualizing and testing random indirect effects and moderated mediation in multilevel models: new procedures and recommendations. Psychological Methods 11(2):142-163.

Bettencourt LA and Brown SW (1997) Contact employees: Relationships among workplace fairness, job satisfaction and prosocial service behaviors. Journal of Retailing 73(1): 39-61.

Chan KW and Wan EW (2012) How can stressed employees deliver better customer service? The underlying self-regulation depletion mechanism. Journal of Marketing 76 (1): 119-137.

Chen Z, Zhu J and Zhou M (2015) How does a servant leader fuel the service fire? A multilevel model of servant leadership, individual self-identity, group competition climate, and customer service performance. Journal of Applied Psychology 100(2): 511-521.

Chiniara M and Bentein K (2016) Linking servant leadership to individual performance:

Differentiating the mediating role of autonomy, competence and relatedness need satisfaction. Leadership Quarterly 27(1): 124-141. 
Cole MS, Bruch H and Shamir B (2009) Social distance as a moderator of the effects of transformational leadership: Both neutralizer and enhancer. Human Relations 62(11): 16971733.

Dimitriades ZS (2007) The influence of service climate and job involvement on customeroriented organizational citizenship behavior in Greek service organizations: A survey. Employee Relations 29(5): 469-491.

Eisenberger R, Karagonlar G, Stinglhamber F, et al. (2010) Leader-member exchange and affective organizational commitment: The contribution of supervisor's organizational embodiment. Journal of Applied Psychology 95(6): 1085-1103.

Eisenberger R, Shoss MK, Karagonlar G, et al. (2014) The supervisor POS-LMX-subordinate POS chain: Moderation by reciprocation wariness and supervisor's organizational embodiment. Journal of Organizational Behavior 35(5): 635-656.

Eldor L and Harpaz I (2016) A process model of employee engagement: The learning climate and its relationship with extra-role performance behaviors. Journal of Organizational Behavior 37(2): 213-235.

Goldstein AP and Sorcher M (1974) Changing Supervisory Behavior. New York: Pergamon. Graham JW (1991) Servant leadership in organizations: Inspirational and moral. Leadership Quarterly 2(2): 105-119.

Greenleaf RK (1970) The Servant as a Leader. Indianapolis, IN: Greenleaf Center.

Greenleaf RK (1977) Servant Leadership: A Journey into the Nature of Legitimate Power and Greatness. New York: Paulist Press.

Heskett J, Sasser WEJ and Schlesinger L (1997) The Service Profit Chain: How Leading Companies Link Profit and Growth to Loyalty, Satisfaction, and Value. New York: Free Press.

Hong Y, Liao H, Hu J and Jiang K (2013) Missing link in the service profit chain: A metaanalytic review of the antecedents, consequences, and moderators of service climate. Journal of Applied Psychology 98(2): 237-267.

Huang J, Li W, Qiu C, Yim FH-K and Wan J (2016) The impact of CEO servant leadership on firm performance in the hospitality industry. International Journal of Contemporary Hospitality Management 28(5): 945-968. 
Hunter EM, Neubert MJ, Perry SJ, et al. (2013) Servant leaders inspire servant followers: Antecedents and outcomes for employees and the organization. Leadership Quarterly 24(2): $316-331$.

James LR (1982) Aggregation bias in estimates of perceptual agreement. Journal of Applied Psychology 67(2): 219-229.

Kalkstein DA, Kleiman T, Wakslak C J, Liberman N and Trope Y (2016) Social learning across psychological distance. Journal of Personality and Social Psychology 110(1): 1-19.

LeBreton JM and Senter JL (2008) Answers to 20 questions about interrater reliability and interrater agreement. Organizational Research Methods 11(4): 815-852.

Liao $\mathrm{H}$ and Chuang A (2004) A multilevel investigation of factors influence employee service performance and customer outcomes. Academy of Management Journal 47(1): 41-58.

Liden RC, Panaccio A, Msuser JD, Hu J and Wayne SJ (2014) Servant leadership: Antecedents, processes, and outcomes. In: Day D (ed.) Oxford Handbook of Leadership and Organizations. New York: Oxford University Press, 357- 379.

Liden RC, Wayne SJ, Liao C and Meuser JD (2014) Servant leadership and serving culture: Influence on individual and unit performance. Academy of Management Journal 57(5): 14341452.

Liden RC, Wayne SJ, Meuser JD, Hu J, Wu J and Liao C (2015) Servant leadership: Validation of a short form of the SL-28. Leadership Quarterly 26(2): 254-269.

Liden RC, Wayne SJ, Zhao H and Henderson D (2008) Servant leadership: Development of a multidimensional measure and multi-level assessment. Leadership Quarterly 19(2): 161-177.

Liu D, Liao H and Loi R (2012) The dark side of leadership: A three-level investigation of the cascading effect of abusive supervision on employee creativity. Academy of Management Journal 55(5): 1187-1212.

Manz CC and Sims HP (1981) Vicarious learning: The influence of modeling on organizational behavior. Academy of Management Review 6(1): 105-113.

Mayer DM, Kuenzi M, Greenbaum R, Bardes M and Salvador R (2009) How low does ethical leadership flow? Test of a trickle-down model. Organizational Behavior and Human Decision Processes 108(1): 1-13. 
Motowidlo SJ and Van Scotter JR (1994) Evidence that task performance should be distinguished from contextual performance. Journal of Applied Psychology 79(4): 475-480.

Netemeyer RG, Maxham III JG and Pullig C (2005) Conflicts in the work-family interface: Links to job stress, customer service employee performance, and customer purchase intent. Journal of Marketing 69(2):130-143.

Neubert MJ, Hunter EM and Tolentino RC (2016) A servant leader and their stakeholders: When does organizational structure enhance a leader's influence? Leadership Quarterly 27(6): 896910.

Peterson SJ, Galvin BM and Lange D (2012) CEO servant leadership: Exploring executive characteristics and firm performance. Personnel Psychology 65(3): 565-596.

Preacher KJ, Rucker DD and Hayes AF (2007) Addressing moderated mediation hypotheses: Theory, methods, and prescriptions. Multivariate Behavioral Research 42(1): 185-227.

Ruiz P, Ruiz C and Martínez R (2011) Improving the "leader-follower" relationship: Top manager or supervisor? The ethical leadership trickle-down effect on follower job response. Journal of Business Ethics 99(4): 587-608.

Schneider B, White SS and Paul MC (1998) Linking service climate and customer perceptions of service quality: Tests of a causal model. Journal of Applied Psychology 83(2): 150-163.

Shoss M, Eisenberger R, Restubog SLD and Zagenczyk TJ (2013) Blaming the organization for abusive supervision: The roles of perceived organizational support and supervisor's organizational embodiment. Journal of Applied Psychology 98(1): 158-168.

Subramony M and Pugh SD (2015) Services management research: Review, integration, and future directions. Journal of Management 41(1): 349-373.

van Dierendonck D (2011). Servant leadership: A review and synthesis. Journal of Management 37(4): 1228-1261.

van Dierendonck D, Stam D, Boersma P, de Windt N and Alkema J (2014) Same difference?

Exploring the differential mechanisms linking servant leadership and transformational leadership to follower outcomes. Leadership Quarterly 25(3): 544-562.

World Bank (2017) World Development Indicators: Structure of Output. Available at: http://wdi.worldbank.org/table/4.2 (accessed 1 May 2017). 
Yaffe T and Kark R (2011) Leading by example: The case of leader OCB. Journal of Applied Psychology 96(4): 806-826. 
Table 1 Descriptive Statistics for Individual-Level (Level 1) Variables $(N=568)$

\begin{tabular}{|c|c|c|c|c|c|c|c|c|c|c|c|}
\hline Variables & $M$ & $S D$ & 1 & 2 & 3 & 4 & 5 & 6 & 7 & 8 & 9 \\
\hline 1. Employee Age & 31.95 & 6.65 & - & & & & & & & & \\
\hline 2. Employee Gender & 1.61 & 0.49 & .01 & - & & & & & & & \\
\hline 3. Employee Education & 2.96 & 0.53 & $-.29^{* *}$ & -.04 & - & & & & & & \\
\hline 4. Employee Dyadic Tenure with Supervisor & 2.37 & 1.13 & $.25^{* *}$ & .02 & -.04 & - & & & & & \\
\hline 5. Employee Service Climate Perception & 4.02 & 0.68 & $-.25^{* *}$ & -.03 & -.00 & -.06 & - & & & & \\
\hline 6. Supervisor Servant Leadership & 3.77 & 0.61 & $-.21^{* *}$ & -.02 & -.01 & $-.13^{* *}$ & $.61^{* *}$ & - & & & \\
\hline 7. Supervisor's Organizational Embodiment & 3.92 & 0.48 & $-.18^{* *}$ & -.04 & .03 & -.05 & $.59^{* *}$ & $.74^{* *}$ & - & & \\
\hline 8. In-Role Service Performance & 4.28 & 0.56 & -.07 & -.03 & -.01 & .05 & $.59^{* *}$ & $.43^{* *}$ & $.43^{* *}$ & - & \\
\hline 9. Extra-Role Service Performance & 3.90 & 0.68 & $-.21^{* *}$ & -.05 & .04 & -.06 & $.67^{* *}$ & $.50^{* *}$ & $.51^{* *}$ & $.67^{* *}$ & - \\
\hline
\end{tabular}

Note. ${ }^{*} p<.05,{ }^{* *} p<.01$.

Table 2 Descriptive Statistics for Group-Level (Level 2) Variables

\begin{tabular}{|c|c|c|c|c|c|c|c|c|c|c|c|c|}
\hline Variables & $M$ & $S D$ & 1 & 2 & 3 & 4 & 5 & 6 & 7 & 8 & 9 & 10 \\
\hline 1. Supervisor Age & 40.09 & 5.90 & - & & & & & & & & & \\
\hline 2. Supervisor Gender & 1.48 & 0.50 & -.17 & - & & & & & & & & \\
\hline 3. Supervisor Education & 2.93 & 0.44 & $-.29^{* *}$ & .04 & - & & & & & & & \\
\hline 4. Supervisor Position Tenure & 2.64 & 1.19 & $.35^{* *}$ & -.19 & -.05 & - & & & & & & \\
\hline 5. Manager Servant Leadership & 3.63 & 0.60 & $-.35^{* *}$ & .08 & -.01 & -.20 & - & & & & & \\
\hline 6. Manager's Organizational Embodiment & 3.98 & 0.66 & -.04 & .03 & -.11 & -.03 & $.63^{* *}$ & - & & & & \\
\hline 7. Supervisor Servant Leadership & 3.82 & 0.60 & $-.30^{* *}$ & .19 & .07 & $-.35^{* *}$ & $.44^{* *}$ & $.21^{*}$ & - & & & \\
\hline 8. Supervisor' s Organizational Embodiment & 3.93 & 0.50 & $-.27^{* *}$ & .18 & .11 & $-.21^{*}$ & $.42^{* *}$ & $.34^{* *}$ & $.74^{* *}$ & - & & \\
\hline 9. In-Role Service Performance & 3.91 & 0.59 & -.01 & $.27^{* *}$ & -.01 & .11 & $.40^{* *}$ & $.46^{* *}$ & $.29^{* *}$ & $.26^{*}$ & - & \\
\hline 10. Extra-Role Service Performance & 3.64 & 0.68 & -.03 & $.25^{*}$ & .02 & .03 & $.40^{* *}$ & $.43^{* *}$ & $.31^{* *}$ & $.29^{* *}$ & $.82^{* *}$ & - \\
\hline
\end{tabular}

Note. Variable 1-6 were rated by supervisors $(N=92)$. Variable 7-10 were aggregated variables based on individual-level data $(N=568)$.

${ }^{*} p<.05,{ }^{* *} p<.01$. 
Table 3 Results of the Cross-Level Effects of Servant Leadership on Employee Service Performance

\begin{tabular}{|c|c|c|c|c|}
\hline \multirow[t]{2}{*}{ Variables } & \multicolumn{2}{|c|}{$\begin{array}{c}\text { In-Role } \\
\text { Service Performance } \\
\text { (Model 1) } \\
\end{array}$} & \multicolumn{2}{|c|}{$\begin{array}{c}\text { Extra-Role } \\
\text { Service Performance } \\
\text { (Model 2) } \\
\end{array}$} \\
\hline & $B\left(\gamma_{\mathrm{ij}}\right)$ & S.E & $B\left(\gamma_{\mathrm{ij}}\right)$ & S.E \\
\hline \multicolumn{5}{|l|}{ Level 1} \\
\hline Employee Age $\gamma_{10}$ & .00 & .00 & .00 & .00 \\
\hline Employee Gender $\gamma_{20}$ & -.01 & .03 & -.01 & .04 \\
\hline Employee Education $\gamma_{30}$ & -.05 & .04 & .04 & .04 \\
\hline Employee Dyadic Tenure with Supervisor $\gamma_{40}$ & .00 & .02 & -.03 & .02 \\
\hline Employee Service Climate Perception $\gamma_{50}$ & $.43^{* *}$ & .04 & $.59^{* *}$ & .04 \\
\hline \multicolumn{5}{|l|}{ Level 2} \\
\hline Intercept $\gamma_{00}$ & $2.81^{* *}$ & .25 & $1.46^{* *}$ & .26 \\
\hline Supervisor Age $\gamma_{02}$ & .00 & .01 & $-.01^{* *}$ & .01 \\
\hline Supervisor Gender $\gamma_{03}$ & -.08 & .05 & -.09 & .05 \\
\hline Supervisor Education $\gamma_{04}$ & .01 & .05 & .03 & .05 \\
\hline Supervisor Position Tenure $\gamma_{05}$ & .04 & .02 & .03 & .03 \\
\hline Supervisor Servant Leadership $\gamma_{06}$ & $.15^{* *}$ & .05 & $.13^{*}$ & .06 \\
\hline Manager Servant Leadership $\gamma_{07}$ & $.11^{*}$ & .04 & -.01 & .05 \\
\hline
\end{tabular}

Note. This table shows the results of two separate "intercepts-as-outcomes" analyses. Level $1 \mathrm{~N}, 568$ frontline employees; level $2 \mathrm{~N}, 92$ sub-branches of the banking company. $B$ represents the unstandardized regression coefficients.

${ }^{*} p<.05,{ }^{* *} p<.01$. 
Table 4 Results of Moderated Mediation

\begin{tabular}{|c|c|c|c|c|c|c|c|c|}
\hline IV & Mediator & DV & $\begin{array}{l}\text { 1st Stage } \\
\text { Moderator } \\
(\mathrm{MOE})\end{array}$ & $\begin{array}{c}\text { 2nd Stage } \\
\text { Moderator } \\
\text { (SOE) }\end{array}$ & $\begin{array}{l}\text { Indirect } \\
\text { Effect }\end{array}$ & S.E & $t$ value & $95 \% \mathrm{CI}$ \\
\hline \multirow{16}{*}{$\begin{array}{l}\text { Manager } \\
\text { Servant } \\
\text { Leadership }\end{array}$} & \multirow{16}{*}{$\begin{array}{l}\text { Supervisor } \\
\text { Servant } \\
\text { Leadership }\end{array}$} & \multirow{8}{*}{$\begin{array}{c}\text { In-Role } \\
\text { Service } \\
\text { Performance }\end{array}$} & Higher & - & .08 & .03 & 2.27 & {$[.01, .14]$} \\
\hline & & & Lower & - & .02 & .02 & 0.83 & {$[-.03, .07]$} \\
\hline & & & - & Higher & .07 & .03 & 2.76 & {$[.02, .12]$} \\
\hline & & & - & Lower & -.00 & .03 & -0.09 & {$[-.06, .06]$} \\
\hline & & & Higher & Higher & .10 & .04 & 2.39 & {$[.02, .19]$} \\
\hline & & & Higher & Lower & -.00 & .04 & -0.09 & {$[-.09, .08]$} \\
\hline & & & Lower & Higher & .03 & .03 & 0.86 & {$[-.04, .09]$} \\
\hline & & & Lower & Lower & -.00 & .01 & -0.09 & {$[-.02, .02]$} \\
\hline & & \multirow{8}{*}{$\begin{array}{c}\text { Extra-Role } \\
\text { Service } \\
\text { Performance }\end{array}$} & Higher & - & .08 & .03 & 2.64 & {$[.02, .13]$} \\
\hline & & & Lower & - & .02 & .02 & 0.88 & {$[-.03, .07]$} \\
\hline & & & - & Higher & .05 & .03 & 1.80 & {$[.004, .09]^{\mathrm{a}}$} \\
\hline & & & - & Lower & -.02 & .03 & -0.47 & {$[-.08, .05]$} \\
\hline & & & Higher & Higher & .07 & .03 & 1.94 & {$[.01, .12]^{\mathrm{a}}$} \\
\hline & & & Higher & Lower & -.02 & .05 & -0.45 & {$[-.11, .07]$} \\
\hline & & & Lower & Higher & .02 & .02 & 0.83 & {$[-.02, .06]$} \\
\hline & & & Lower & Lower & -.01 & .01 & -0.39 & {$[-.03, .02]$} \\
\hline
\end{tabular}

Note. This table shows the results for the tests of H4a, H4b, and H5. First-stage moderated mediation was tested based on Model 2 in Preacher et al. (2007). Second-stage moderated mediation was tested based on Model 3 in Preacher et al. (2007). The combined moderated mediation was tested based on Model 4 in Preacher et al. (2007). Bold numbers indicate that the indirect effect is significant or marginally significant. IV = independent variable, $\mathrm{DV}=$ dependent variable, $S . E=$ standard error, $\mathrm{CI}=$ confidence interval. ${ }^{\mathrm{a}} 90 \%$ confidence interval.

${ }^{*} p<.05,{ }^{* *} p<.01$. 
Figure 1 Research Model

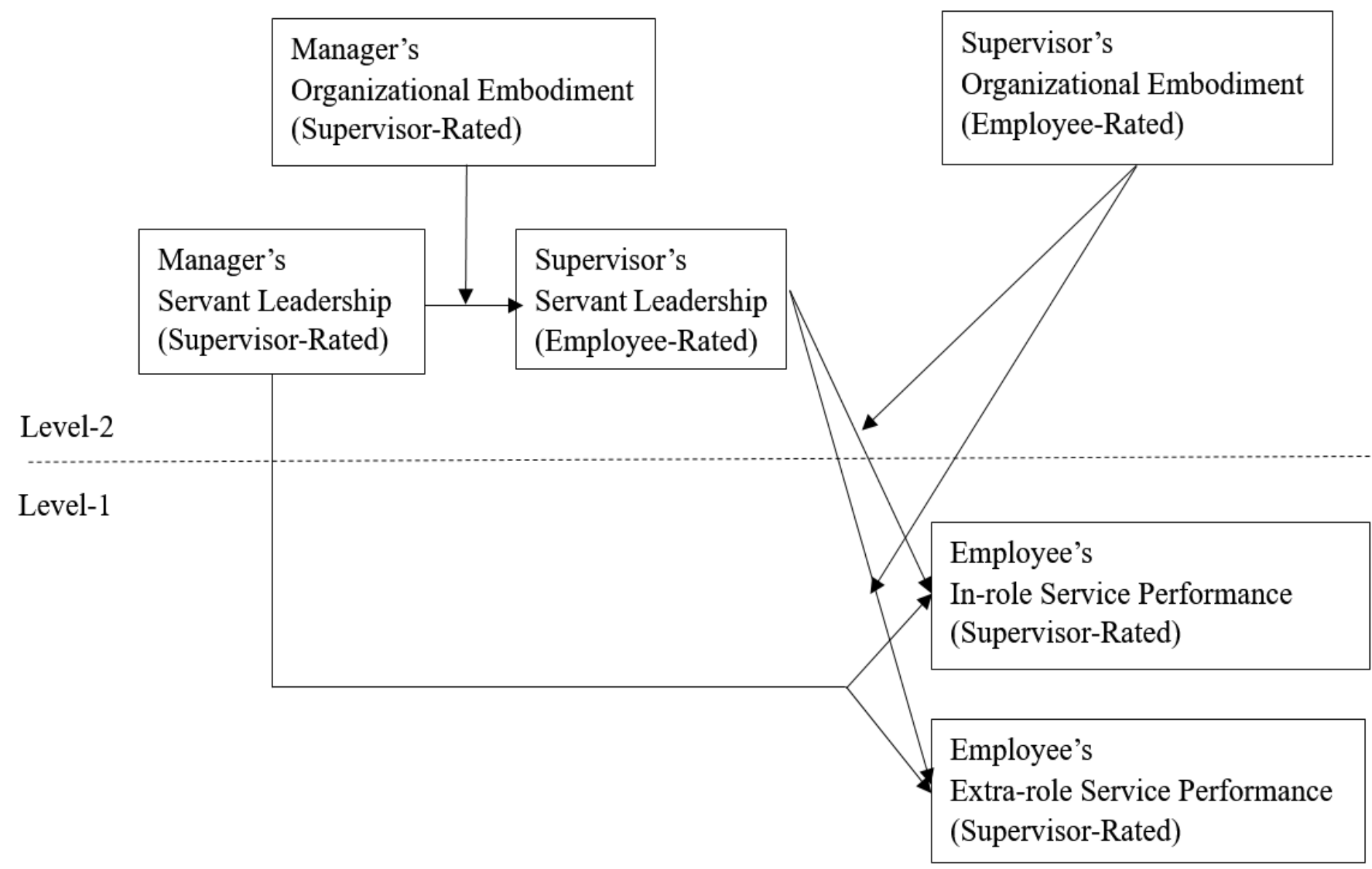


Figure 2a The Interactive Effect of MSL and MOE on Supervisor's Servant Leadership

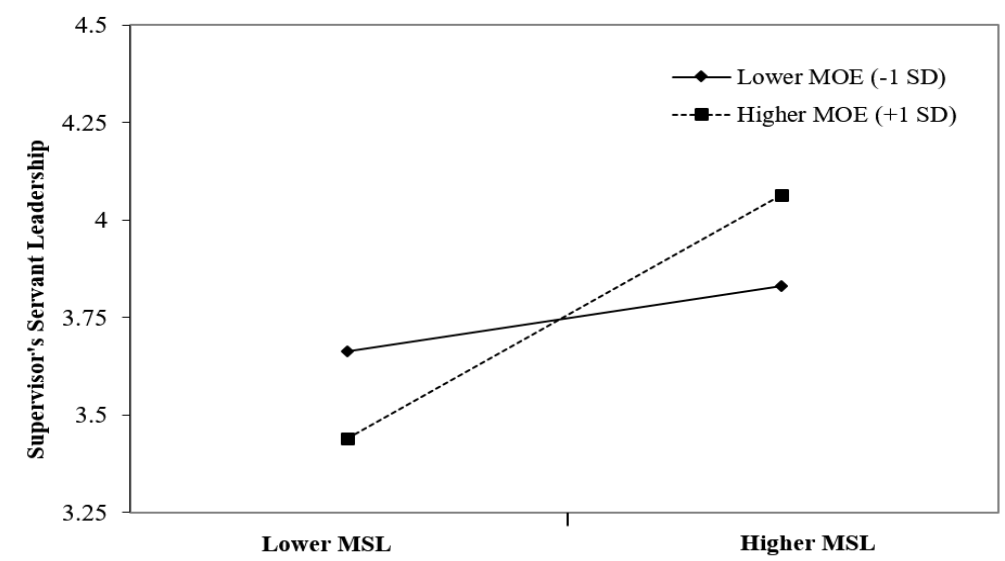

Figure $2 \mathrm{~b}$ The Interactive Effect of SSL and SOE on Employee's In-role Service Performance

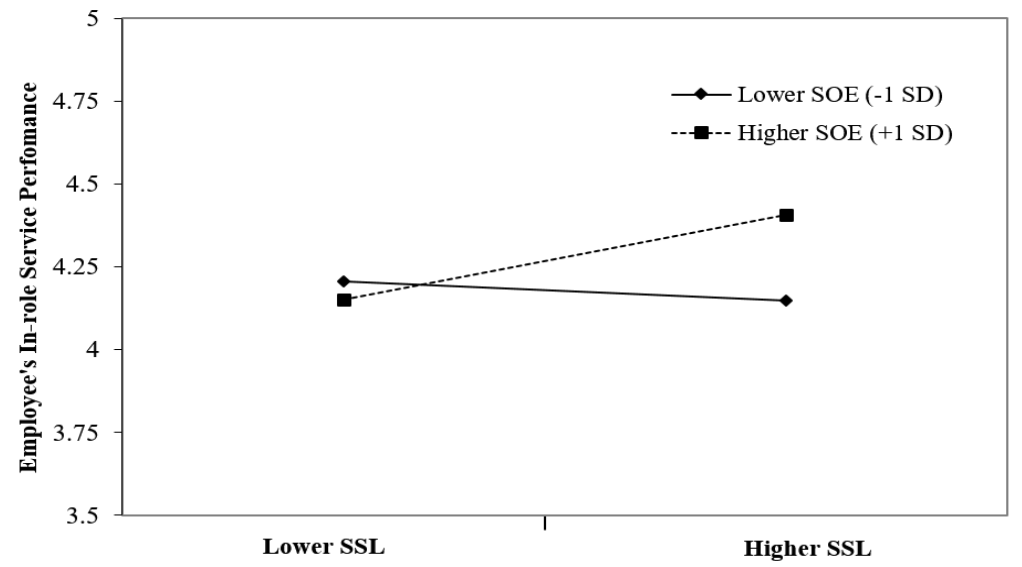

Figure 2c The Interactive Effect of SSL and SOE on Employee's Extra-role Service Performance

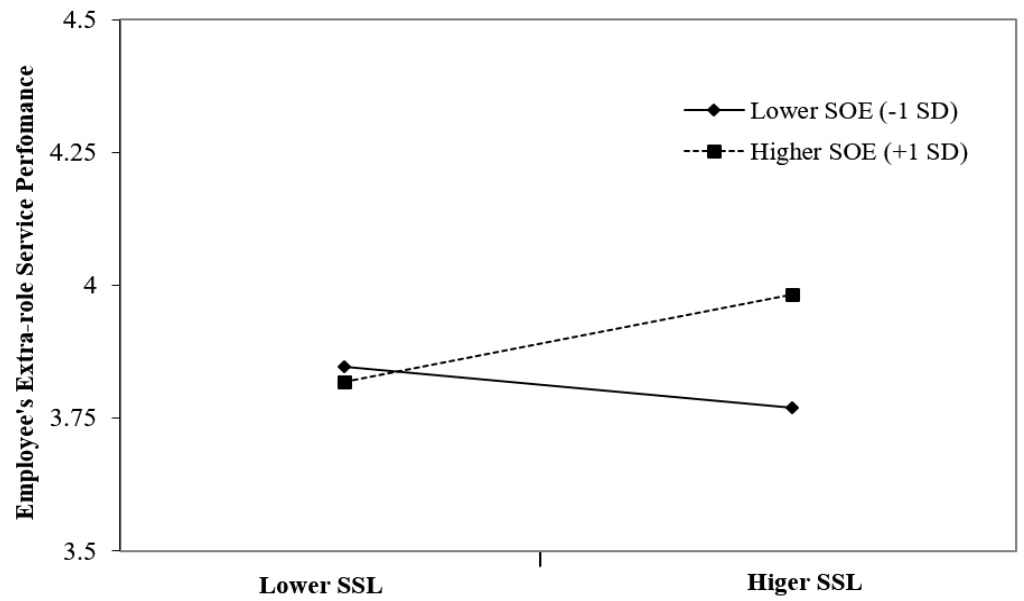

Note. $\mathrm{MSL}=$ Manager's Servant Leadership; MOE = Manager's Organizational Embodiment; $\mathrm{SSL}=$ Supervisor's Servant Leadership; SOR = Supervisor' Organizational Embodiment. 